\title{
IGF-I-induced enhancement of contractile response in organ-cultured aortae from diabetic rats is mediated by sustained thromboxane $A_{2}$ release from endothelial cells
}

\author{
Tsuneo Kobayashi, Takayuki Matsumoto and Katsuo Kamata \\ Department of Physiology and Morphology, Institute of Medicinal Chemistry, Hoshi University, Shinagawa-ku, Tokyo 142-8501, Japan \\ (Requests for offprints should be addressed to K Kamata; Email: kamata@hoshi.ac.jp)
}

\begin{abstract}
We have investigated the mechanisms underlying the changes in vascular contractile responsiveness induced by insulin and IGF-I in established streptozotocin-induced diabetic rats. The contractile response to noradrenaline (NA) in organ-cultured diabetic rat aortae cultured with insulin or IGF-I was significantly greater than the corresponding responses in (a) diabetic rat aortae cultured in serum-free medium and (b) control rat aortae cultured with insulin or IGF-I. In aortae from which the endothelium was removed after organ culture the contractile response to NA was greater in those cultured with insulin or IGF-I than in those cultured in serum-free medium. This was not true of aortae endothelium denuded before organ culture. The IGF-I-induced enhancement was prevented by treatment with indomethacin (cyclooxygenase inhibitor), SQ29548 (thromboxane (TX) $\mathrm{A}_{2}$ receptor antagonist) or fregrelate $\left(\mathrm{TXA}_{2}\right.$ synthase inhibi-
\end{abstract}

tor). IGF-I-induced production of $\mathrm{TXB}_{2}$, a metabolite of $\mathrm{TXA}_{2}$, was greater in diabetic than in control aortae and was attenuated by endothelium denudation, indomethacin or AG1024 (IGF-I receptor inhibitor). The expression of the protein and mRNA for the IGF-I receptor (as assessed by RT-PCR and immunohistochemistry) was markedly increased within endothelial cells in diabetic aortae but only slightly increased within smooth muscle cells (versus control rat aortae). Thus, the NA-induced contractile response in aortae from diabetic rats was enhanced by both insulin and IGF-I and this enhancement may be mediated by sustained cyclo-oxygenase-dependent TXA $_{2}$ production from endothelial cells. The observed enhancement of IGF-I receptor expression within endothelial cells may be causally related to the potentiation of vascular contractility and the increase in $\mathrm{TXA}_{2}$ production.

Journal of Endocrinology (2005) 186, 367-376

\section{Introduction}

Diabetes mellitus is an important risk factor for increased blood pressure and for the development of atherosclerosis (Cohen 1995, Feener \& King 1997, Kirpichnikov \& Sowers 2001, Eckel et al. 2002). The elevated plasma insulin level seen in diabetes has long been thought to contribute to the pathogenesis of these conditions (Standly et al. 1993, Hall et al. 1995, Reaven 1995, Abe et al. 1998, Kobayashi et al. 2004). One of the possibilities raised by in vitro studies is that hyperinsulinaemia may result in an increased sensitivity of blood vessels to vasoconstrictors such as angiotensin II or catecholamines (Gans et al. 1991, Townsend et al. 1992, Hall et al. 1995, Kobayashi \& Kamata 1999).

Insulin-like growth factor-I (IGF-I) - a homologue of insulin that shares many signalling components and cellular responses with insulin itself (Blakesley et al. 1996, Chisalita \& Arnqvist 2004) - has been shown to affect smooth muscle cell migration and proliferation (Bornfeldt et al.
1992, Duan et al. 2000, Delafontaine et al. 2004). Moreover, chronic overexpression of IGF-I in transgenic mice results in enhanced aortic and cardiac contractility (Zhao et al. 2001, Norby et al. 2004). The relationship between the IGF system and the complications associated with diabetes is particularly apparent for retinopathy, nephropathy and neuropathy (Jehle et al. 1998, Raz et al. 1998, Smith et al. 1999, Gerhardinger et al. 2001) but less apparent for macrovascular disease.

Although both insulin and IGF-I reportedly increase $\alpha_{1}$-adrenoceptor expression in rat vascular smooth muscle cells (Hu et al. 1996), there is evidence that the high insulin levels found in patients with insulinomas or in control rats subjected to high-dose insulin treatments do not cause hypertension or an enhancement in vascular function (Hall et al. 1995, Kobayashi \& Kamata 1999). However, a few years ago we demonstrated that in aortae isolated from rats with established streptozotocin (STZ)-induced diabetes, high-dose insulin treatment can enhance noradrenaline (NA)-induced contractility 
(and presumably blood pressure) (Kobayashi \& Kamata 1999). Furthermore, we have directly shown that longterm culture with insulin or IGF-I enhances NA-induced aortic vasocontractility only when the cultured aortae are from diabetic rats, not when they are from control animals (Kobayashi et al. 2003). We postulated that a perturbation of the activity and/or function of the insulin and IGF-I system in diabetes could be a key event leading to an enhancement of vascular contraction, although the underlying mechanism is unknown.

The main aim of the present study was therefore to investigate the mechanism underlying the change in vascular contractile responsiveness induced by insulin/ IGF-I in aortae from established STZ-induced diabetic rats. We used organ culture of the entire vascular wall (Ozaki \& Karaki 2002, Kobayashi et al. 2003) because in this way it is possible to incubate the tissue with a constant concentration of IGF-I for a prolonged period of time and because direct interactions between vascular smooth muscle cells and endothelial cells can easily be examined.

\section{Materials and Methods}

\section{Reagents}

STZ, NA, insulin, IGF-I, fregrelate sodium salt, 5,8,11,14-eicosatetraynoic acid (ETYA), SQ29548 $\mathrm{N}^{\mathrm{G}}$ nitro-L-arginine (L-NOARG) were all purchased from Sigma Chemical Co. (St Louis, MO, USA). AACOCF 3 and tyrphostin AG1024 were from Calbiochem (La Jolla, CA, USA). NS398 and CAY10404 were from Cayman Chemical (Ann Arbor, MI, USA). Drugs were dissolved in saline or, in the case of tyrphostin AG1024, $\mathrm{AACOCF}_{3}$, ETYA, NS398, SQ29548 and CAY10404, in dimethyl sulphoxide.

\section{Animals and experimental design}

Male Wistar rats, 8 weeks old and $180-250 \mathrm{~g}$ in weight, received a single injection via the tail vein of STZ $(65 \mathrm{mg} / \mathrm{kg})$ dissolved in a citrate buffer. Age-matched control rats were injected with the buffer alone. Food and water were given ad libitum. This study was conducted in accordance with the Guide for the Care and Use of Laboratory Animals adopted by the Committee on the Care and Use of Laboratory Animals of Hoshi University (which is accredited by the Ministry of Education, Culture, Sports, Science, and Technology, Japan).

\section{Organ culture procedure}

The organ culture procedure involved a method described previously (Kobayashi et al. 2003). Briefly, each aorta was cleaned of loosely adhering fat and connective tissue, then cut into helical strips $3 \mathrm{~mm}$ in width and $20 \mathrm{~mm}$ in length.
Either before or after incubation (as required by that particular experiment), the endothelium was removed by rubbing the intimal surface with a cotton swab. Successful denudation was confirmed by the absence of a relaxation to $10^{-5} \mathrm{M}$ acetylcholine. Strips were then placed in $5 \mathrm{ml}$ serum-free Leibovitz's L-15 medium supplemented with $1 \%$ penicillin-streptomycin. Some strips were placed in a similar solution containing $500 \mathrm{ng} / \mathrm{ml}$ insulin, $20 \mathrm{ng} / \mathrm{ml}$ IGF-I or $20 \mathrm{ng} / \mathrm{ml}$ IGF-I plus one of a number of inhibitors $\left(10^{-5} \mathrm{M}\right.$ indomethacin, $3 \times 10^{-6} \mathrm{M}$ SQ29548, $10^{-4} \mathrm{M}$ fregrelate, $10^{-6} \mathrm{M} \mathrm{AACOCF}_{3}, 10^{-6} \mathrm{M}$ ETYA, $3 \times 10^{-6} \mathrm{M}$ CAY10404, $3 \times 10^{-6} \mathrm{M}$ NS398, $2 \times 10^{-8} \mathrm{M}$ or $2 \times 10^{-7} \mathrm{M}$ tyrphostin AG1024 or $10^{-4} \mathrm{M}$ L-NOARG). Strips were incubated at $37^{\circ} \mathrm{C}$ for $16 \mathrm{~h}$. After incubation, the endothelium (if present) was removed and the tissue placed in a bath of Krebs-Henseleit solution (KHS) at $37^{\circ} \mathrm{C}$ with one end connected to a tissue holder and the other to a force-displacement transducer. The release of thromboxane (TX) $\mathrm{A}_{2}$, measured as its stable metabolite $\mathrm{TXB}_{2}$, was determined using a $\mathrm{TXB}_{2}$ enzymeimmunoassay system (Amersham Biosciences, Piscataway, NJ, USA). The amount of $\mathrm{TXB}_{2}$ released was expressed as $\mathrm{pg} / \mathrm{mg}$ wet weight of aorta.

\section{Measurement of isometric force}

Rats were anaesthetized with diethyl ether and killed by decapitation 10 weeks after treatment with STZ or buffer. The aorta (cut into helical strips) was placed in a bath containing $10 \mathrm{ml}$ modified KHS (bubbled with 95\% $\mathrm{O}_{2}$ plus $5 \% \mathrm{CO}_{2}$, and kept at $37^{\circ} \mathrm{C}$ ), with one end of each strip connected to a tissue holder and the other to a force-displacement transducer, as previously described (Kobayashi \& Kamata 1999). In some preparations, the endothelium was removed by rubbing the intimal surface with a cotton swab, successful removal being functionally confirmed by the absence of a relaxation to $10^{-5} \mathrm{M}$ acetylcholine. For the contraction studies, NA $\left(10^{-10}\right.$ to $\left.10^{-5} \mathrm{M}\right)$, isotonic high $\mathrm{K}^{+}(10$ to $80 \mathrm{mM})$ or angiotensin II $\left(10^{-9}\right.$ to $\left.10^{-6} \mathrm{M}\right)$ were added cumulatively to the bath until a maximal response was achieved. After the addition of sufficient aliquots of the agonist to produce the chosen concentration, a plateau response was allowed to develop before the addition of the next dose of the same agonist.

\section{$R N A$ isolation and RT-PCR}

RNA isolation Aortae were carefully isolated from six control or STZ-treated rats and cleaned of adhering parenchyma and connective tissue. Endothelial cells were detached by rubbing the intimal surface with a micro brush, then washed off using RNA buffer. The collected RNA buffer (pooled from six rat aortae) was used to examine the RNA expression profile of endothelial cells, while the remainder of each aortic strip was used to examine that of smooth muscle cells. The RNA was 
Table 1 PCR primers and PCR protocols

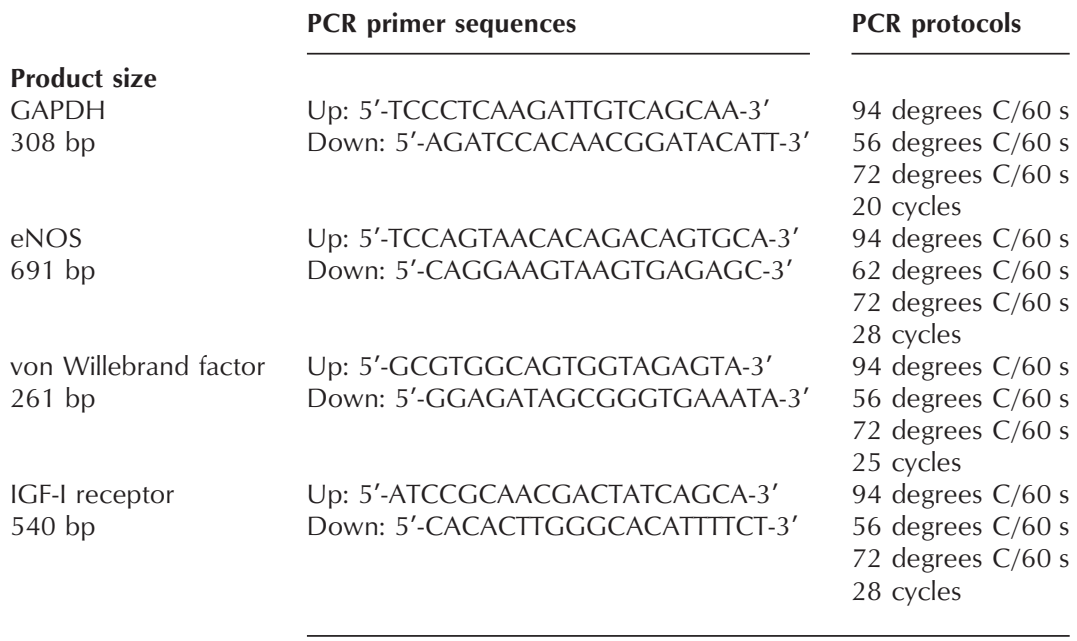

isolated by the guanidinium method, then quantified by ultraviolet absorbance spectrophotometry. RT-PCR analysis of endothelial markers was performed using oligonucleotides specific for endothelial nitric oxide synthase (eNOS) and von Willebrand factor (vWF).

Oligonucleotides The primers used are summarized in Table 1.

Measurement of mRNA expressions by RT-PCR RT-PCR was assayed by the method described previously (Kobayashi et al. 2003). In the present study, RT-PCR was applied to the total RNA isolated from aortic smooth muscle or endothelial cells obtained from control or diabetic rats. For the RT-PCR analysis, first-strand cDNA was synthesized from total RNA (1 $\mu \mathrm{g})$ using Oligo (dT)12-18 and a ThermoScript RT-PCR System (Invitrogen Corp., Carlsbad, CA, USA). Twenty (glyceraldehyde-3-phosphate dehydrogenase (GAPDH)), twenty-five (vWF) or twenty-eight (eNOS or IGF receptor) PCR cycles $\left(94{ }^{\circ} \mathrm{C}\right.$ for $1 \mathrm{~min}, 56{ }^{\circ} \mathrm{C}$ for $1 \mathrm{~min}, 72{ }^{\circ} \mathrm{C}$ for $1 \mathrm{~min}$ ) were performed using one half of the reverse transcription mixture. Following an analysis of reaction products at two to three cycle increments to examine the linear phase of amplification, a total of 20 cycles was chosen for the quantitation of GAPDH and 28 cycles for that of the IGF-I receptor. The products obtained were quantified by scanning densitometry, the amounts being normalized with respect to the amount of GAPDH product.

\section{Immunohistochemistry}

IGF-I receptor protein expression was visualized by immunohistochemical staining of control or diabetic aortae that had been frozen in OCT compound (Sakura,

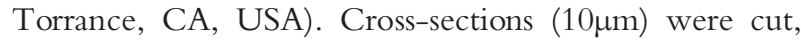
then dried onto slides for $45 \mathrm{~min}$. Sections were fixed in cold acetone, with endogenous peroxide being blocked using $0 \cdot 3 \%$ hydrogen peroxide. Non-specific protein binding was blocked by a 30-min incubation in Block ace (Dainipponpharm, Osaka, Japan). Sections were then incubated for $1 \mathrm{~h}$ with polyclonal anti-IGF-I $\beta$ chain receptor (1:100 dilution; Santa Cruz Biotechnology, Santa Cruz, CA, USA) or anti-vWF (1:200; Sigma Chemical Co). Horseradish-peroxidase-conjugated, anti-rabbit antibody (Vector Laboratories, Burlingame, CA, USA) was used at a 1:500 dilution in Tween phosphate-buffered saline. The staining was visualized by means of the reaction with 3,3'-diaminobenzidine tetrahydrochloride (Vector Laboratories).

\section{Statistical analysis}

The contractile force developed by aortic strips from control and diabetic rats is expressed in $\mathrm{mg}$ tension/mg tissue. Data are expressed as the means \pm S.E.M. When appropriate, statistical differences were determined by Dunnett's test for multiple comparisons after a one- or two-way ANOVA, a probability level of $P<0 \cdot 05$ being regarded as significant. Statistical comparisons between concentration-response curves were made using a oneway ANOVA, with Bonferroni's correction for multiple comparisons being performed post hoc $(P<0.05$ again being considered significant).

\section{Results}

Plasma glucose and insulin levels

As in our previous study (Kobayashi \& Kamata 1999), at the time of the experiment all STZ-treated rats exhibited 
hyperglycaemia, their blood glucose concentrations $(543.1 \pm 22.45 \mathrm{mg} / \mathrm{dl}, n=12)$ being significantly higher than those of the age-matched, non-diabetic control rats $(102 \cdot 8 \pm 5 \cdot 4 \mathrm{mg} / \mathrm{dl}, n=12(P<0 \cdot 001))$. Plasma insulin levels were significantly lower in the STZ-induced diabetics $(4 \cdot 8 \pm 1 \cdot 2 \mu \mathrm{U} / \mathrm{dl}, n=12(P<0 \cdot 001))$ than in the controls $(32 \cdot 7 \pm 4 \cdot 9 \mu \mathrm{U} / \mathrm{dl}, n=12)$.

Contractile response to $\mathrm{NA}$ in aortae cultured with insulin or IGF-I

We used organ culture of the entire control or diabetic aortic wall because this method allows incubation of the tissue with a constant concentration of insulin or IGF-I for a prolonged period of time and because morphological and functional changes in the tissue can be easily examined. The main substances in the plasma that influence vascular tone are NA (the agent used in the present study) and adrenaline (Vargas \& Gorman 1995). In aortae incubated in serum-free medium, NA induced a contraction of a magnitude similar to that induced by NA in fresh aortae (data not shown). The concentrations of insulin and IGF-I were chosen on the basis of previous data (Hu et al. 1996, Kobayashi et al. 2003). Incubating control rat aortae with insulin $(500 \mathrm{ng} / \mathrm{ml})$ or IGF-I $(20 \mathrm{ng} / \mathrm{ml})$ for $16 \mathrm{~h}$ had no significant effect on the contraction induced by NA in aortic strips that had been denuded of endothelium after the incubation (Fig. 1A). In diabetic aortae incubated for $16 \mathrm{~h}$ with insulin $(500 \mathrm{ng} / \mathrm{ml})$ or IGF-I $(20 \mathrm{ng} / \mathrm{ml}$ and $50 \mathrm{ng} / \mathrm{ml}$ ) the NA-induced contraction in strips denuded of endothelium after the incubation was significantly greater than the corresponding contraction observed in (a) diabetic aortae incubated in serum-free medium or (b) control rat aortae incubated with insulin or IGF-I (Fig. 1B). In contrast to the above results obtained in aortic strips denuded of endothelium after incubation, incubation with insulin or IGF-I had no effect on the contraction induced by NA in strips denuded of endothelium before incubation in either the control group (Fig. 2A) or the diabetic group (Fig. 2B). Incubating diabetic aortae for only $30 \mathrm{~min}$ in medium containing either insulin $(500 \mathrm{ng} /$ $\mathrm{ml})$ or IGF-I $(20 \mathrm{ng} / \mathrm{ml})$ had no effect on the contraction induced by NA in strips endothelium denuded after the incubation (data not shown). Incubating control or diabetic aortae (endothelium denuded after incubation) with low-dose insulin (10 or $50 \mathrm{ng} / \mathrm{ml}$ ) or low-dose IGF-I $(2 \mathrm{ng} / \mathrm{ml})$ had no significant effects on the contraction induced by NA (data not shown).

To investigate the possible mechanism underlying the above enhancement of contraction by IGF-I in the diabetic aorta, all subsequent experiments were carried out using diabetic aortic preparations endothelium denuded after incubation. As shown in Fig. 3A, co-incubation with $10^{-5} \mathrm{M}$ indomethacin, a non-selective cyclo-oxygenase inhibitor, prevented the IGF-I-induced enhancement of contraction. However, neither $3 \times 10^{-6} \mathrm{M}$ CAY10404
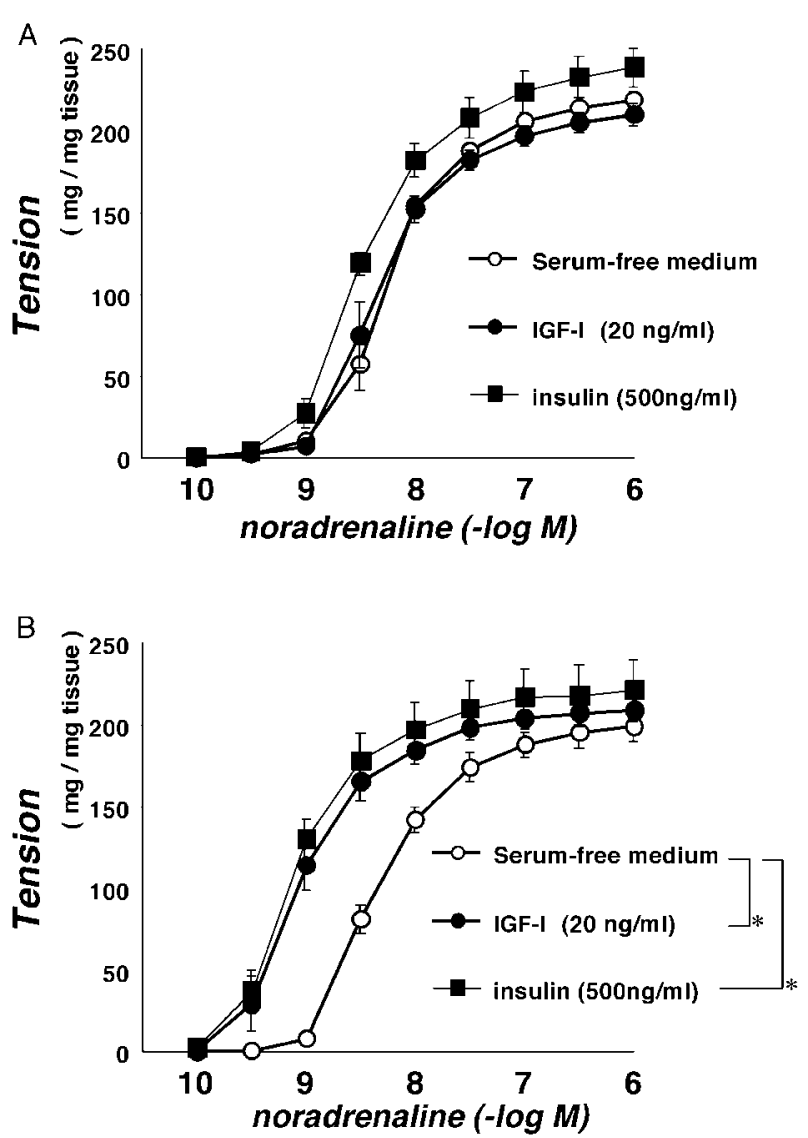

Figure 1 Concentration-response curves for NA-induced contractions in aortic strips from which endothelium was removed after organ culture. Strips from (A) age-matched controls and (B) diabetic rats were cultured in serum-free medium or in the presence of either insulin $(500 \mathrm{ng} / \mathrm{ml})$ or IGF-I $(20 \mathrm{ng} / \mathrm{ml})$ for $16 \mathrm{~h}$. The ordinate shows increase in tension (expressed in $\mathrm{mg}$ tension/mg tissue) measured at the peak of the response. Each data point represents the mean \pm S.E.M. from six to eight experiments; the S.E.M. is included only when it exceeds the dimension of the symbol used. ${ }^{*} P<0 \cdot 05$ vs diabetic aortae cultured in serum-free medium.

nor $3 \times 10^{-8} \mathrm{M}$ NS398, selective cyclo-oxygenase-2 inhibitors, had this effect (Fig. 3A). Co-incubation with $10^{-6} \mathrm{M} \mathrm{AACOCF}_{3}$ or $10^{-6} \mathrm{M}$ ETYA, phospholipase $\mathrm{A}_{2}$ $\left(\mathrm{PLA}_{2}\right)$ inhibitors, also prevented the IGF-I-induced enhancement of contraction (Fig. 3B), as did co-incubation with $3 \times 10^{-6} \mathrm{M}$ SQ29548 (a TXA 2 receptor antagonist) or $10^{-4} \mathrm{M}$ fregrelate (a TXA 2 synthase inhibitor) (Fig. $3 \mathrm{C}$. However, coincubation with $5 \times 10^{-9} \mathrm{M} \mathrm{J}-104132$, an endothelin receptor-A/B antagonist, or with $10^{-4} \mathrm{M}$ L-NOARG, an NO synthase inhibitor did not have this effect (data not shown).

Exposure of aortic strips to isotonic high $\mathrm{K}^{+}$(10 to $80 \mathrm{mM})$ or angiotensin II $\left(10^{-9}\right.$ to $\left.10^{-6} \mathrm{M}\right)$ led to a concentration-dependent rise in tension in all experimental groups, and there was no significant difference in 

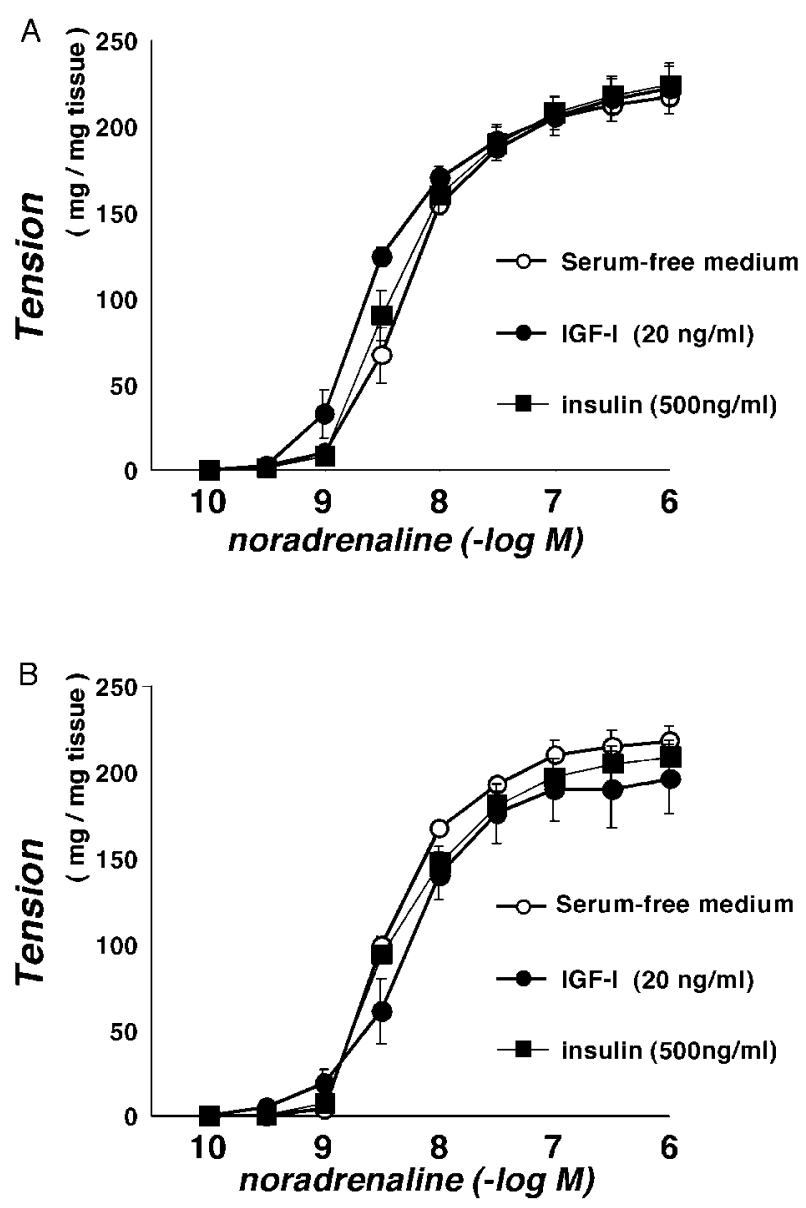

Figure 2 Concentration-response curves for NA-induced contractions in aortic strips from which endothelium was removed before culture. Strips from (A) age-matched controls and (B) diabetic rats were cultured in serum-free medium or in the presence of either insulin $(500 \mathrm{ng} / \mathrm{ml})$ or IGF-I $(20 \mathrm{ng} / \mathrm{ml})$ for $16 \mathrm{~h}$. The ordinate shows increase in tension (expressed in $\mathrm{mg}$ tension/mg tissue) measured at the peak of the response. Each data point represents the mean \pm S.E.M. from six to eight experiments; the S.E.M. is included only when it exceeds the dimension of the symbol used.

sensitivity among the various IGF-I-treated groups (i.e. those incubated with IGF-I with or without the above inhibitors (data not shown).

\section{Release of $\mathrm{TXB}_{2}$}

In endothelium-intact aortae, the basal concentration of $\mathrm{TXB}_{2}$ in the serum-free medium was not different between aortae from control and diabetic rats. Incubating such aortae with IGF-I increased the release of $\mathrm{TXB}_{2}$ in strips from diabetic rats (versus IGF-I-untreated aortae) but not in those from control rats (Fig. 4). This IGF-Iinduced release of $\mathrm{TXB}_{2}$ was considerably decreased by co-incubation with indomethacin, co-incubation with
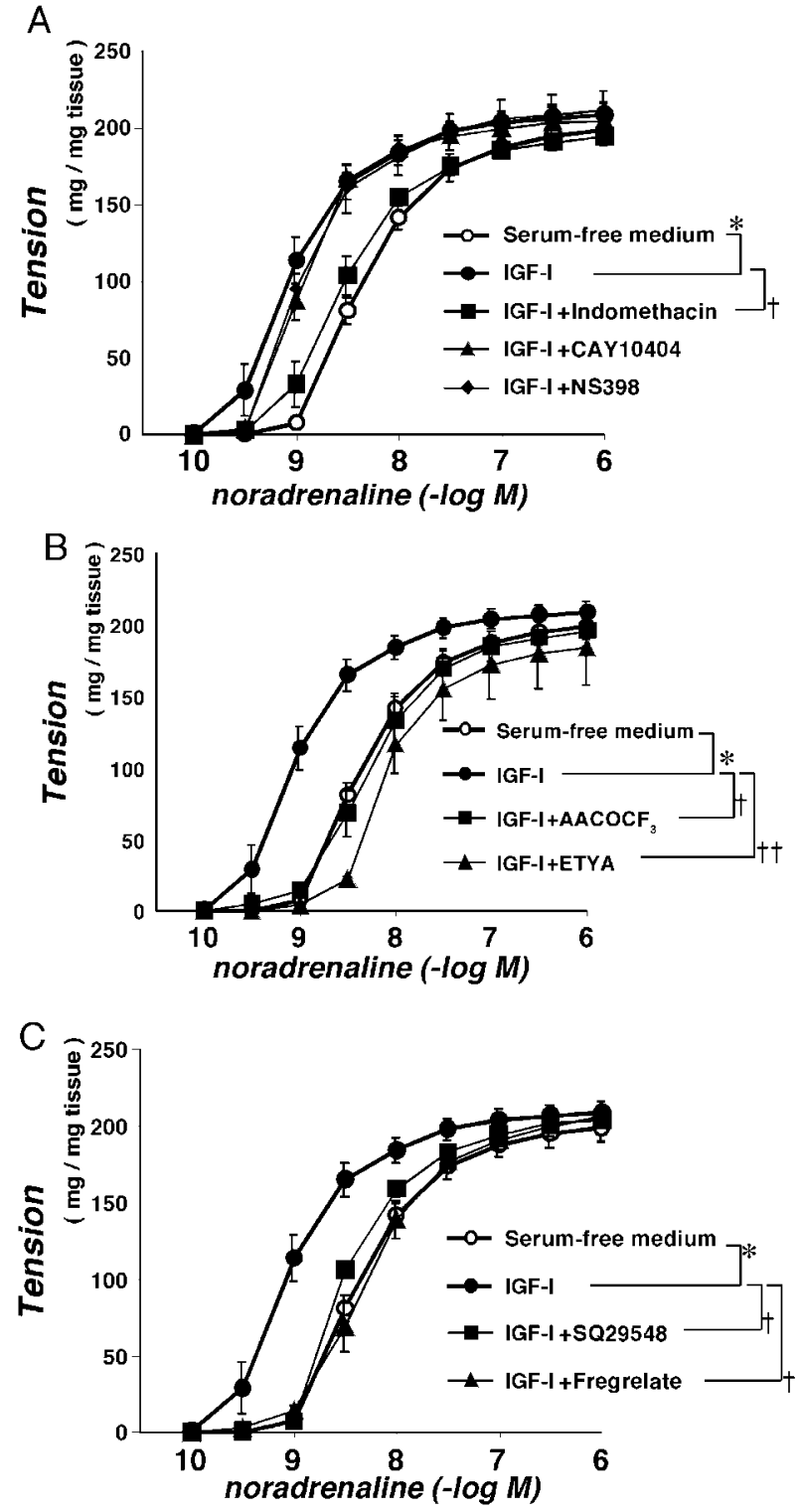

Figure 3 Concentration-response curves for NA-induced contractions in aortic strips after culture in serum-free medium or in the presence of IGF-I $(20 \mathrm{ng} / \mathrm{ml})$, (A) together with effects of co-incubation with indomethacin $\left(10^{-5} \mathrm{M}\right)$ and CAY10404 $\left(3 \times 10^{-6} \mathrm{M}\right)$ and NS398 $\left(3 \times 10^{-8} \mathrm{M}\right),(\mathrm{B}) \mathrm{AACOCF}_{3}\left(10^{-6} \mathrm{M}\right)$ and ETYA $\left(10^{-6} \mathrm{M}\right)$ and $(\mathrm{C}) \mathrm{SQ} 29548\left(3 \times 10^{-6} \mathrm{M}\right)$ and fregrelate $\left(10^{-4} \mathrm{M}\right)$ on the IGF-I-enhanced contraction. The ordinate shows the increase in tension (expressed in $\mathrm{mg}$ tension/mg tissue) measured at the peak of the response. Each data point represents the mean \pm S.E.M. from six to eight experiments; the S.E.M. is included only when it exceeds the dimension of the symbol used. ${ }^{*} P<0.05$ vs diabetic aortae in serum-free medium. $+P<0 \cdot 05$ and $++P<0 \cdot 01$ vs diabetic aortae cultured with IGF-I alone.

$2 \times 10^{-7} \mathrm{M}$ (but not with $2 \times 10^{-8} \mathrm{M}$ ) AG1024, an IGF-I receptor inhibitor, or by endothelium denudation in aortae from either control or diabetic rats (Fig. 4). 


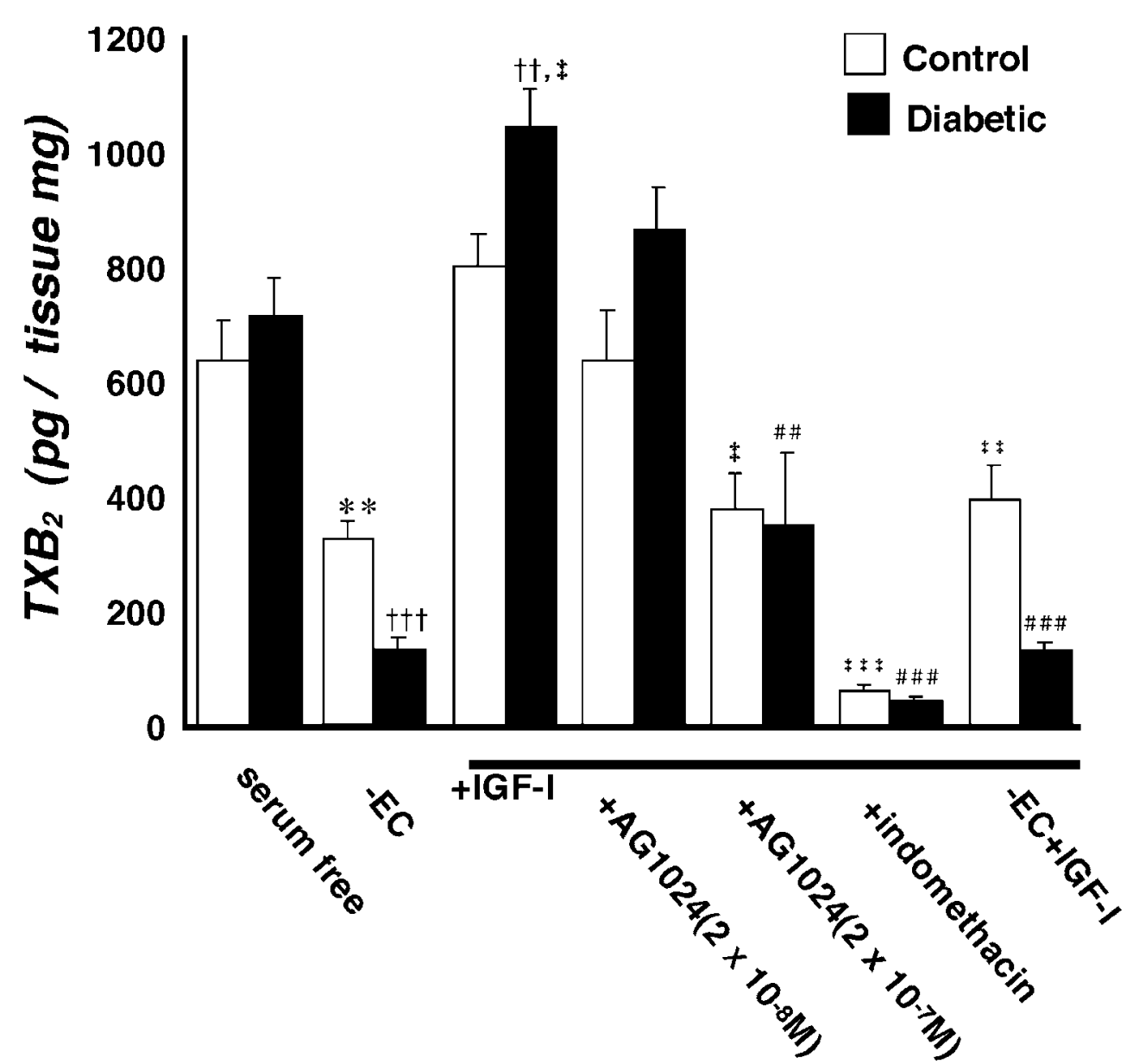

Figure 4 Release of TXB ${ }_{2}$ upon IGF-I stimulation of organ-cultured aortae from control and STZ-induced diabetic rats, together with effects of endothelium denudation, indomethacin and AG1024. Serum free, aortae cultured in serum-free medium; +IGF-I, IGF-I-stimulated; AG1024, AG1024+IGF-I; - EC, endothelium denuded; - EC+IGF-I, endothelium denuded+IGF-I; +indomethacin, indomethacin+IGF-I. Values are the mean \pm S.E.M. of six determinations. ${ }^{* *} P<0 \cdot 01 \mathrm{vs}$ control aortae in serum-free medium; $\dagger+P<0.01$ and $\dagger+\uparrow P<0.001$ vs diabetic aortae in serum-free medium; $\ddagger P<0.05, \neq \neq P<0.01$ and $\neq \neq \ddagger P<0.001$ vs control aortae cultured with IGF-I; \#\#P<0.01 and \#\#\#P<0.001 vs diabetic aortae cultured with IGF-I.

In endothelium-denuded aortae, both the basal release and the IGF-induced release of $\mathrm{TXB}_{2}$ were smaller in aortae from diabetic rats than in those from control rats.

\section{Expression of the $m R N A$ for IGF-I receptor in vascular} smooth muscle cells and endothelial cells

Using RT-PCR on the total RNA isolated from the vascular smooth muscle cells or endothelial cells of aortae from control and diabetic rats, we found the following. RT-PCR analysis of endothelial markers was performed using specific oligonucleotides. After 28 or 25 PCR cycles, positive expressions for eNOS and vWF were detected only in the total RNA from endothelial cells, not in that from smooth muscle cells (Fig. 5A). For the IGF-I receptor and GAPDH, the amplifications were performed using 17 , 20, 23, 25, 28, 30 and 33 cycles. The band intensities for both the IGF-I receptor and GAPDH were PCR amplification-cycle dependently increased and had nearly reached a plateau by 30-33 (IGF-I receptor) and 25-30 (GAPDH) cycles. A total of 28 cycles was chosen for the quantitation of the IGF-I receptor and 20 for GAPDH. The expression of GAPDH mRNA in smooth muscle cells showed no difference between aortae from control and diabetic rats. The expression of the mRNA for the IGF-I receptor tended to be slightly increased in vascular smooth muscle cells from diabetics (versus controls), but this was not significant. By contrast, in the total RNA from 
A
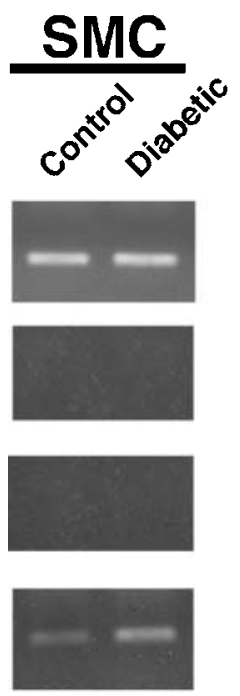
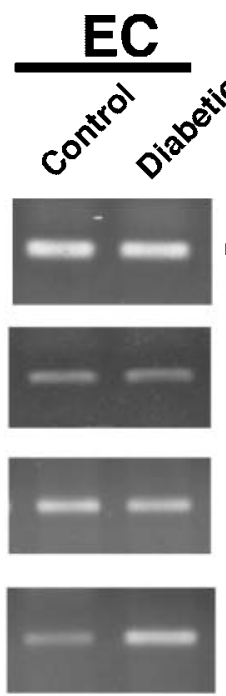

B

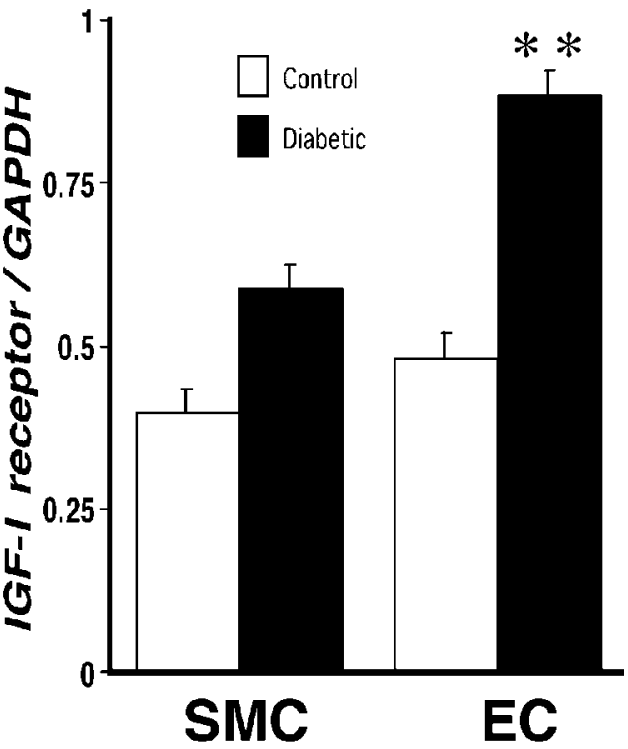

Figure 5 RT-PCR assays of mRNA expression for IGF-I receptor (IGF-I-R) in control and diabetic rat aortae. (A) Expression of mRNAs for GAPDH, eNOS, vWF and IGF-I receptor in aortic smooth muscle cells (SMC) or endothelial cells (EC) as assayed by RT-PCR. (B) Quantitative analysis of expression of the mRNA for IGF-I receptor in aortic smooth muscle cells or endothelial cells (by scanning densitometry). Control rats ( $n=6$, open columns) and STZ-induced diabetic rats $(n=6$, solid columns) are shown. Values are means \pm S.E.M. of six determinations (IGF-I receptor/GAPDH). ${ }^{* *} P<0.01$ diabetic vs control.

endothelial cells the expression of IGF-I receptor mRNA was significantly greater in the diabetic group than in the control group (Fig. 5B).

\section{Immunohistochemistry}

We also examined staining for IGF-I receptor protein within the vascular smooth muscle and endothelial cells of rat aortae. Immunohistochemical analysis of endothelial markers was also performed for $\mathrm{vWF}$ in aortae from control and diabetic rats. Positive staining for $\mathrm{vWF}$ was detected only in endothelial cells, not in smooth muscle cells (Fig. 6A and B). By contrast, positive staining for IGF-I receptor protein was detected within vascular smooth muscle cells in the media and as well as within endothelial cells. Although the positive staining for the IGF-I receptor within vascular smooth muscle cells was slightly increased in the diabetic rats, that within endothelial cells was markedly increased in diabetic rats (Fig. 6C and D).

\section{Discussion}

The main conclusion to be drawn from the present study was that, in aortae isolated from established STZ-induced diabetic rats, the IGF-I-induced enhancement of the contractile response to NA shown by organ-cultured aortae was mediated by sustained $\mathrm{TXA}_{2}$ release from endothelial cells. Furthermore, this enhancement in the diabetic aorta may be related to the increase in the expression of the IGF-I receptor observed within endothelial cells in this vessel.

In recent years, we and others have reported that the presence of an enhanced vasoactivity for both insulin and IGF-I is directly associated with increased vascular contractility (Zhao et al. 2001, Kobayashi et al. 2003). In the present study, culture of aortae with insulin or IGF-I enhanced NA-induced vasocontractility in aortae denuded of endothelium after the culture period but only when the aortae were both from diabetic rats and subjected to long-term $(16 \mathrm{~h})$ culture, not when they were from control rats nor when they were subjected to short-term (30 min) culture. Interestingly, removal of the aortic endothelium before the culture period prevented the vasoactive effects of insulin and IGF-I. The endothelium produces a number of vasoconstrictors that serve to regulate vascular smooth muscle tone, including angiotensin, endothelin and cyclo-oxgenase products (Cohen 1995). Our results suggested that sustained production of certain substance(s) from the endothelium somehow enhances vascular contraction in smooth muscle cells. In the present 

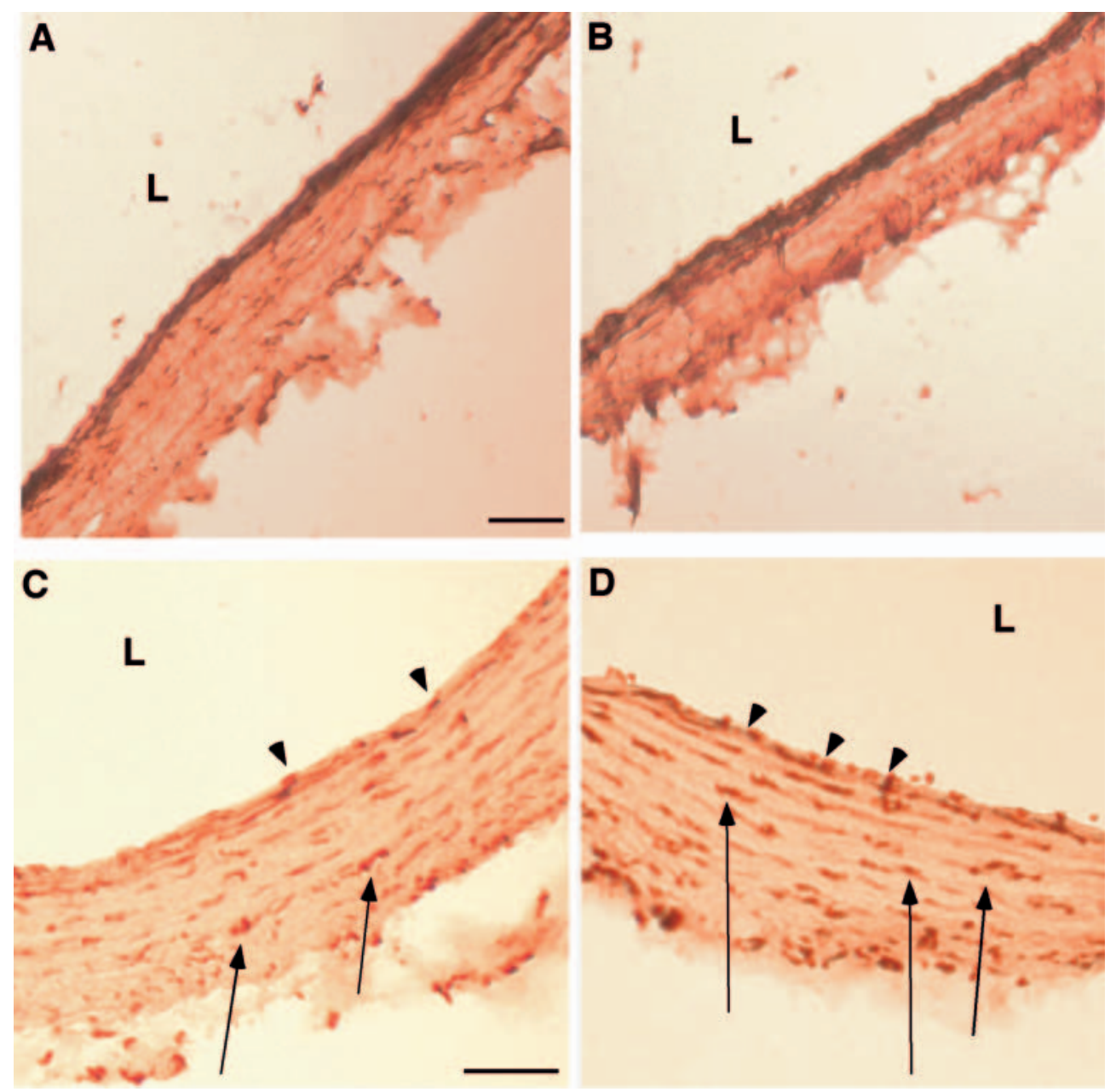

Figure 6 Expression of (A and B) CWF and (C and D) IGF-I receptor proteins in frozen sections of aortae from ( $A$ and $C$ ) control and (B and D) diabetic rats, as assessed by immunohistochemical staining. Positive staining for VWF protein was detected mainly within endothelial cells. IGF-I receptor protein was detected within both endothelial cells and vascular smooth muscle cells. A marked increase in the IGF-I receptor within endothelial cells was observed in the diabetic rat aortae. Calibration bars, $25 \mu \mathrm{m}$. Representative pictures from five or six independent experiments are shown. L, lumen; arrows, smooth muscle cells; arrowheads, endothelial cells.

study, the enhancement effect observed with IGF-I in the diabetic aorta was prevented by co-incubation with (a) indomethacin, a non-selective cyclo-oxygenase inhibitor or (b) either $\mathrm{AACOCF}_{3}$ or ETYA, PLA 2 inhibitors. Moreover, SQ29548 or fregrelate $\left(\mathrm{TXA}_{2}\right.$ receptor and synthase inhibitors respectively) prevented this enhancement effect of IGF-I. These results suggested that the IGF-I-induced enhancement of the NA response is mediated at least partly through the $\mathrm{PLA}_{2}$ /cyclooxygenase-1/TXA 2 synthase pathway present within endothelial cells.

In the tail artery and in small mesenteric arteries, insulin preincubation has been reported to stimulate cyclooxygenase-dependent prostaglandin production by endo- thelial cells (Rebolledo et al. 2001, Miller et al. 2002). In the present study, the TXA ${ }_{2}$ level, measured as $\mathrm{TXB}_{2}$, was increased by IGF-I in the culture medium from diabetic aortae, but IGF-I induced no such change in (a) control aortae or (b) endothelium-denuded or indomethacintreated diabetic aortae. From these results, we cannot be sure that it was release of $\mathrm{TXA}_{2}$ during culture that was responsible for increasing the NA-induced contraction in the diabetic aorta following culture with IGF-I. However, it has been reported that low concentrations of the TXA analogue U-46619 enhance the contractile effect of NA in the human saphenous vein (Vila et al. 2001). This raises the possibility that such an enhancement effect, due to increased $\mathrm{TXA}_{2}$ production, could be mediated by 
alterations at the receptor level; for example, by events leading to an increased affinity of NA for its receptor. Indeed, such a mechanism could entirely account for the present observations because the contraction induced by isotonic $\mathrm{K}^{+}$, which is mediated by voltage-dependent calcium channels, was not potentiated by IGF-I. A possible scenario is that IGF-I and insulin each stimulate $\mathrm{TXA}_{2}$ synthesis within endothelial cells in the diabetic aorta, leading to a sustained increase in the vascular level of its products, and suggesting that the IGF-I-induced enhancement of the NA response is mediated through the $\mathrm{TXA}_{2}$ synthase pathway present within endothelial cells in this vessel. Further, if the potentiating effect of IGF-I is indeed due to a modulation of events involved in $\alpha$-adrenergic stimulation, this effect may be a general one affecting vascular smooth muscle cells in other vessels. However, this idea remains to be tested.

The results of several studies suggest that the effects of insulin on endothelial cells and smooth muscle cells may be mediated primarily via its stimulatory effects on the IGF-I receptor (King et al. 1985, Bornfeldt et al. 1992, Jamali et al. 2003). Using immunohistochemistry and RT-PCR, we found that the expression of the IGF-I receptor was increased in the endothelial cells of the diabetic rat aorta (versus those of the control rat aorta) but not in the smooth muscle cells. Thus, the enhanced IGF-I and insulin responsiveness shown by the diabetic, but not control, aorta may be related to a difference between control and diabetic rats in the population of IGF-I receptors present in the endothelial cells in this vessel. The IGF-I receptor has been shown to be highly expressed in atherosclerotic lesions and also in arteries in hypertension and diabetes (Grant et al. 1994, Raisanen-Sokolowski et al. 1994, Polanco et al. 1995), while insulin or IGF-I treatment of the diabetic aorta seems able to increase NA-induced contractions (the present study). Ours is first direct evidence of an increased expression of the IGF-I receptor in endothelial cells in the diabetic rat. By contrast, in previous in vitro studies, IGF-I and insulin have each been shown to induce endothelium-dependent $\mathrm{NO}$ production and vasodilatation in aortae and mesenteric arteries from diabetic rats (Wu et al. 1994, Walsh et al. 1996, Kobayashi \& Kamata 2002). Such an effect might help to limit cardiovascular damage during hyperinsulinaemia. We previously reported that for the latter effect of insulin, one possible explanation is that it may upregulate eNOS via the IGF-I receptor, thereby resulting in an improvement in endothelial function in STZ-induced diabetes (Kobayashi \& Kamata 2002). In pathological states, it is conceivable that the above vasodilator or constrictor effects of insulin and IGF-I may be impaired or potentiated to different extents, so the resultant overall effect of insulin or IGF-I might be hypertensive, involving enhancement of vascular constriction, in at least some cases (if the enhancement of constriction occurs in vessels with a significant impact on total peripheral resistance). Indeed, it has been shown that inhibition of thromboxane synthesis attenuates hyperinsulinaemia-induced hypertension in the rat (Keen et al. 1997). This being so, it may be that IGF-I- and insulin-induced $\mathrm{TXA}_{2}$ release from endothelial cells during the diabetic stage is sufficient to counteract their vasodilator effects (and the resulting decrease in blood pressure).

It has been reported that endothelial dysfunction in diabetes diminishes both the activity and production of $\mathrm{NO}$, and enhances the endothelial production of $\mathrm{TXA}_{2}$ (Cohen 1995). In the present study, however, coincubation with L-NOARG, an NO synthase inhibitor, did not alter the insulin/IGF-I-induced effects. These observations suggest that IGF-I- and insulin-induced $\mathrm{TXA}_{2}$ release is independent of a decrease in NO production by diabetic endothelial cells.

In conclusion, our findings have suggested that, in organ-cultured aortae, the NA-induced contractile response shown by aortae from STZ-induced diabetic rats may be enhanced by both insulin and IGF-I and that this effect may be mediated by sustained cyclo-oxygenase-1dependent TXA ${ }_{2}$ production by endothelial cells. Furthermore, the enhancement of IGF-I receptor expression in endothelial cells that we observed in the diabetic rat aorta may be related to this potentiation of vascular contractility and the increased $\mathrm{TXA}_{2}$ production. Our results have provided functional evidence suggesting the possibility that drugs that antagonize the actions of $\mathrm{TXA}_{2}$ may have clinical potential as agents providing protection against the possible deleterious vascular effects of the increases in plasma insulin levels that occur in diabetes.

\section{Funding}

This study was supported in part by the Ministry of Education, Culture, Sports, Science and Technology, Japan, by the Promotion and Mutual Aid Cooperation for Private Schools of Japan, and by the Suzuken Memorial Foundation, Japan. The authors declare that there is no conflict of interest that would prejudice the impartiality of this scientific work.

\section{References}

Abe H, Yamada N, Kamata K, Kuwaki T, Shimada M, Osuga J, Shionoiri F, Yahagi N, Kadowaki T, Tamemoto H, Ishibashi S, Yazaki Y \& Makuuchi M 1998 Hypertension, hypertriglyceridemia, and impaired endothelium-dependent vascular relaxation in mice lacking insulin receptor substrate-1. Journal of Clinical Investigation 101 1784-1788.

Blakesley VA, Scrimgeour A, Esposito D \& Le Roith D 1996 Signaling via the insulin-like growth factor-I receptor: does it differ from insulin receptor signaling? Cytokine Growth Factor Reviews $\mathbf{7}$ 153-159.

Bornfeldt KE, Arnqvist HJ \& Capron L 1992 In vivo proliferation of vascular smooth muscle in relation to diabetes mellitus, insulin-like growth factor I and insulin. Diabetologia 35 104-108. 
Chisalita SI \& Arnqvist HJ 2004 Insulin-like growth factor I receptors are more abundant than insulin receptors in human micro- and macrovascular endothelial cells. American Journal of PhysiologyEndocrinology and Metabolism 286 E896-E901.

Cohen RA 1995 The role of nitric oxide and other endotheliumderived vasoactive substances in vascular disease. Progress in Cardiovascular Diseases 38 105-128.

Delafontaine P, Song YH \& Li Y 2004 Expression, regulation, and function of IGF-1, IGF-1R, and IGF-1 binding proteins in blood vessels. Arteriosclerosis Thrombosis and Vascular Biology 24 435-444.

Duan C, Bauchat JR \& Hsieh T 2000 Phosphatidylinositol 3-kinase is required for insulin-like growth factor-I-induced vascular smooth muscle cell proliferation and migration. Circulation Research 86 15-23.

Eckel RH, Wassef M, Chait A, Sobel B, Barrett E, King G, Lopes-Virella M, Reusch J, Ruderman N, Steiner G \& Vlassara H 2002 Prevention Conference VI: Diabetes and Cardiovascular Disease: Writing Group II: pathogenesis of atherosclerosis in diabetes. Circulation 105 138-143.

Feener EP \& King GL 1997 Vascular dysfunction in diabetes mellitus. Lancet 350 9-13.

Gans RO, Bilo HJ, von Maarschalkerweerd WW, Heine RJ, Nauta JJ \& Donker AJ 1991 Exogenous insulin augments in healthy volunteers the cardiovascular reactivity to noradrenaline but not to angiotensin II. Journal of Clinical Investigation 88 512-518.

Gerhardinger C, McClure KD, Romeo G, Podesta F \& Lorenzi M 2001 IGF-I mRNA and signaling in the diabetic retina. Diabetes 50 175-183.

Grant MB, Wargovich TJ, Ellis EA, Caballero S, Mansour M \& Pepine CJ 1994 Localization of insulin-like growth factor I and inhibition of coronary smooth muscle cell growth by somatostatin analogues in human coronary smooth muscle cells. A potential treatment for restenosis? Circulation 89 1511-1517.

Hall JE, Brands MW, Zappe DH \& Galicia MA 1995 Insulin resistance, hyperinsulinaemia, and hypertension: causes, consequences, or merely correlations? Proceeding of the Society for Experimental Biology and Medicine 208 317-329.

Hu ZW, Shi XY \& Hoffman BB 1996 Insulin and insulin-like growth factor I differentially induce $\alpha_{1}$-adrenergic receptor subtype expression in rat vascular smooth muscle cells. Journal of Clinical Investigation 98 1826-1834.

Jamali R, Bao M \& Arnqvist HJ 2003 IGF-I but not insulin inhibits apoptosis at a low concentration in vascular smooth muscle cells. Journal of Endocrinology 179 267-274.

Jehle PM, Jehle DR, Mohan S \& Bohm BO 1998 Serum levels of insulin-like growth factor system components and relationship to bone metabolism in Type 1 and Type 2 diabetes mellitus patients. Journal of Endocrinology 159 297-306.

Keen HL, Brands MW, Smith MJ Jr, Shek EW \& Hall JE 1997 Inhibition of thromboxane synthesis attenuates insulin hypertension in rats. American Journal of Hypertension 10 1125-1131.

King GL, Goodman AD, Buzney S, Moses A \& Kahn CR 1985 Receptors and growth-promoting effects of insulin and insulin-like growth factors on cells from bovine retinal capillaries and aorta. Journal of Clinical Investigation 75 1028-1036.

Kirpichnikov D \& Sowers JR 2001 Diabetes mellitus and diabetesassociated vascular disease. Trends in Endocrinology and Metabolism 12 225-230.

Kobayashi T \& Kamata K 1999 Effect of insulin treatment on smooth muscle contractility and endothelium-dependent relaxation in rat aortae from established STZ-induced diabetes. British Journal of Pharmacology 127 835-842.

Kobayashi T \& Kamata K 2002 Short-term insulin treatment and aortic expressions of IGF-1 receptor and VEGF mRNA in diabetic rats. American Journal of Physiology - Heart and Circulation Physiology 283 H1761-H1768.

Kobayashi T, Kaneda A \& Kamata K 2003 Possible involvement of IGF-1 receptor and IGF-binding protein in insulin-induced enhancement of noradrenaline response in diabetic rat aorta. British Journal of Pharmacology 140 285-294.
Kobayashi T, Taguchi K, Yasuhiro T, Matsumoto T \& Kamata K 2004 Impairment of PI3-K/Akt pathway underlies attenuated endothelial function in aorta of type 2 diabetic mouse model. Hypertension 44 956-962.

Miller AW, Tulbert C, Puskar M \& Busija DW 2002 Enhanced endothelin activity prevents vasodilation to insulin in insulin resistance. Hypertension 40 78-82.

Norby FL, Aberle NS 2nd, Kajstura J, Anversa P \& Ren J 2004 Transgenic overexpression of insulin-like growth factor I prevents streptozotocin-induced cardiac contractile dysfunction and $\beta$-adrenergic response in ventricular myocytes. Journal of Endocrinology 180 175-182.

Ozaki H \& Karaki H 2002 Organ culture as a useful method for studying the biology of blood vessels and other smooth muscle tissues. Japanese Journal of Pharmacology 89 93-100.

Polanco JI, Berciano MT, Lafarga M, Leon J, Pocovi M \& Rodriguez-Rey JC 1995 Expression of insulin-like growth factor receptor mRNA in rabbit atherosclerotic lesions. Biochemical and Biophysical Research Communications 209 182-190.

Raisanen-Sokolowski A, Tilly-Kiesi M, Ustinov J, Mennander A, Paavonen T, Tikkanen MJ \& Hayry P 1994 Hyperlipidemia accelerates allograft arteriosclerosis (chronic rejection) in the rat. Arteriosclerosis, Thrombosis and Vascular Biology 14 2032-2042.

Raz I, Rubinger D, Popovtzer M, Gronbaek H, Weiss O \& Flyvbjerg A 1998 Octreotide prevents the early increase in renal insulin-like growth factor binding protein 1 in streptozotocin diabetic rats. Diabetes 47 924-930.

Reaven GM 1995 Pathophysiology of insulin resistance in human disease. Physiological Reviews 75 473-486.

Rebolledo A, Rinaldi GJ, Milesi V, Gomez Alvis A \& Grassi de Gende AO 2001 Insulin preincubation effects on rat vessel contractile responses: role of the endothelium. Endothelium 8 269-276.

Smith LE, Shen W, Perruzzi C, Soker S, Kinose F, Xu X, Robinson G, Driver S, Bischoff J, Zhang B, Schaeffer JM \& Senger DR 1999 Regulation of vascular endothelial growth factor-dependent retinal neovascularization by insulin-like growth factor-1 receptor. Nature Medicine 5 1390-1395.

Standly P, Bakir M \& Sower JR 1993 Vascular insulin abnormalities, hypertension, and accelerated atherosclerosis. American Journal of Kidney Diseases 21 39-46.

Townsend RR, Yamamoto R, Nickols M, DiPette DJ \& Nickols GA 1992 Insulin enhances pressor responses to norepinephrine in rat mesenteric vasculature. Hypertension 19 II105- II110.

Vargas HM \& Gorman AJ 1995 Vascular alpha-1 adrenergic receptor subtypes in the regulation of arterial pressure. Life Science $\mathbf{5 7}$ 2291-2308

Vila JM, Martinez-Leon JB, Medina P, Segarra G, Ballester RM, Otero E \& Lluch S 2001 U-46619-induced potentiation of noradrenergic constriction in the human saphenous vein: antagonism by thromboxane receptor blockade. Cardiovascular Research 52 462-467.

Walsh MF, Barazi M, Pete G, Muniyappa R, Dunbar J \& Sowers JR 1996 Insulin-like growth factor 1 diminishes in vivo and in vitro vascular contractility: role of vascular nitric oxide. Endocrinology 137 1798-1803.

Wu H, Jeng YY, Yue C, Chyu K, Hsueh WA \& Han TM 1994 Endothelial-dependent vascular effects of insulin and insulin-like growth factor 1 in the perfused rat mesenteric artery and aortic rings. Diabetes $\mathbf{4 3}$ 1027-1032.

Zhao G, Sutliff RL, Weber CS, Wang J, Lorenz J, Paul RJ \& Fagin JA 2001 Smooth muscle-targeted overexpression of insulin-like growth factor I results in enhanced vascular contractility. Endocrinology 142 623-632.

Received 3 March 2005

Accepted 9 June 2005

Made available online as an

Accepted Preprint 14 June 2005 